\title{
O niektórych schematach w internetowej autoprezentacji żeńskich zgromadzeń zakonnych
}

\author{
On some schemes in the online self-presentation \\ of female religious congregations
}

\author{
Katarzyna Czarnecka \\ Wydział Filologii Polskiej i Klasycznej, Uniwersytet Adama Mickiewicza w Poznaniu, \\ ul. Fredry 10, 61-701 Poznań, Polska; \\ e-mail: czar.ka@amu.edu.pl
}

\begin{abstract}
Abstrakt
Celem artykułu jest odszukanie powtarzalnych elementów treściowych i formalnych, widocznych na stronach internetowych żeńskich zgromadzeń zakonnych w Polsce. Strony te są formą medialnej autoprezentacji wspólnot zakonnych, służą informacji, a pośrednio - kreacji wizerunku zgromadzeń. Badaniami objęto 93 strony internetowe zgromadzeń, uczestniczących w Konferencji Wyższych Przełożonych Żeńskich Zgromadzeń Zakonnych. Autorka wyodrębnia 4 aspekty przekazu, składające się na schematy autoprezentacji: 1. podstawy identyfikacji wspólnoty, 2. obszary autocharakterystyki, 3. zaproszenie do kontaktu, 4. multimedialność. Jako prawdopodobną przyczynę przewidywalnej struktury analizowanych stron głównych wskazuje się relację między zakładanym zbiorowym nadawcą a niedookreślonym odbiorcą komunikatu internetowego.
\end{abstract}

Słowa kluczowe: mediatyzacja; autoprezentacja; kreacja wizerunku; język religijny; schemat.

\begin{abstract}
The article aims at finding repetitive content and formal elements visible on the websites of female religious congregations in Poland. These websites are a form of media self-presentation of religious communities, they serve informational purposes and, indirectly, the creation of the image of the congregations. The research covered 93 websites of congregations participating in the Conference of Senior Superiors of Religious Congregations. The author distinguishes 4 aspects of the message that add up to the schemes of self-presentation: 1 . basis of identification of the community, 2. areas of self-description, 3. invitation to contact, 4 . multimedia. The author indicates a relationship between the presumed collective originator and the undefined recipient of the internet message as a probable cause of the predictable structure of the websites analyzed.
\end{abstract}

Keywords: mediatization; self-presentation; image creation; religious language; scheme.

Jedną z możliwości, oferowanych przez technologie internetowe, jest tworzenie stron, których cel polega na powiadamianiu o istnieniu ich gospodarza (niekiedy również właściciela): osoby, instytucji, przedsiębiorstwa, grupy sformalizowanej lub nieformalnej. Równie istotna jest charakterystyka bohatera strony, budowana w sposób, który pozwala nie tylko na dostrzeżenie danej jednostki lub społeczności oraz zdobycie podstawowych informacji, ale i ukształto- 
wanie w umyśle odbiorcy ich możliwie korzystnego wizerunku (zob. Borkowski, Stasiuk-Krajewska red. 2011). W kreacji wizerunku przynajmniej w pewnym stopniu uczestniczy podmiot przedstawiany; wśród możliwych ról wymieńmy inspiratora, zleceniodawcę, konstruktora struktury dokumentu elektronicznego, autora lub selekcjonera udostępnianych materiałów. Udział ten, niezależnie od rzeczywistego autorstwa czy wykonawstwa, sprawia, że intencjonalnie mamy do czynienia nie tyle z prezentacją, co z autoprezentacją; strona internetowa traktowana jest jako narzędzie przedstawiania siebie samego, a także „kontrolowania przez jednostkę sposobu, w jaki jest postrzegana przez otoczenie" (Jeżowska, Treček b.r.). Autoprezentacja może dotyczyć także grupy, zbiorowości, pewnego trwałego lub konstytuowanego doraźnie organizmu społecznego. Posłużenie się Internetem w miejsce kontaktu face-to-face lokuje autoprezentację w obrębie relacji medialnie zapośredniczonych, interface-to-interface, o których pisze Tomasz Goban-Klas (2011: 182).

$\mathrm{W}$ ponaddwudziestoletniej historii Internetu w Polsce poczesne miejsce zajmują działania związane z umieszczaniem w sieci treści religijnych. Badaniami językoznawczymi objęto dotąd obecne w Internecie wybrane gatunki komunikacji religijnej, takie jak np. modlitwy, modlitewniki, świadectwa, przepowiednie, rozmowy duchowe, rekolekcje, słowniki (zob. Zdunkiewicz-Jedynak 2006; Wojtak 2011, Nowak 2005; Kładoczny 2004; K. Czarnecka 2012: 51-63; 2015b: 3343; 2015a: 17-35; Zdunkiewicz-Jedynak red. 2010). Na uwagę zasługują także bardzo liczne, rozbudowane strony internetowe przedstawiające różnego typu wspólnoty religijne ${ }^{1}$. Opis (lub samoopis ${ }^{2}$ ) wspólnoty przy użyciu narzędzia, jakim jest strona internetowa, to kształt komunikacji medialnej, wyraz swoistej, niekoniecznie profesjonalnej polityki informacyjnej. Funkcjonowanie strony internetowej może stanowić przykład eklezjalnej aktywności wizerunkowej-określenia tego używa Igor Borkowski (2011: 57).

Celem niniejszego opracowania jest oparty na analizie stron internetowych wstępny opis sposobów prezentacji żeńskich zgromadzeń zakonnych w Polsce. Podstawę materiałową stanowią 93 strony internetowe, których adresy opublikowano na oficjalnej liście zgromadzeń uczestniczących w Konferencji Wyższych Przełożonych Żeńskich Zgromadzeń Zakonnych33. Wykaz obejmuje 100 wspólnot $20 \mathrm{z}$ nich nie podaje adresu strony, niektóre zaś odsyłają do kilku adresów, np. oddzielnych dla poszczególnych prowincji ${ }^{4}$. Mimo zróżnicowania układu

\footnotetext{
${ }^{1}$ Strona internetowa jest przestrzenią pojemną, umożliwia ulokowanie w jej wnętrzu rozmaitych form genologicznych; ich klasyfikacja pozostaje poza zakresem niniejszego opracowania.

2 Terminem samoopis posługuje się np. K. Stasiuk-Krajewska w artykule Funkcje i struktura dziennikarskiego samoopisu - przypadek „Naszego Dziennika” (2011: 41-55).

3 Tabela dostępna na stronie: http://www.zakony-zenskie.pl/index.php/czlonkinie-konferencji [dostęp: 2.06.2014]. Dla porządku należy zaznaczyć, że nie wszystkie adresy zawarte w tabeli są aktualne.

${ }^{4}$ Niektóre strony internetowe nie zawierają bezpośrednich informacji o zgromadzeniu - np. strona Wspólnoty Niepokalanej Matki Wielkiego Zawierzenia (http://www.zawierzanki.pl/) powia-
} 
i grafiki przegląd stron ujawnia pewną przewidywalność - schematyczność - treści; w efekcie stosunkowo trudno jest wyłowić oraz zapamiętać cechy szczególne.

Analiza stron internetowych wymaga uwzględnienia ich podstawowej cechy: hipertekstowości (Bauer 2006: 75-76; zob. też: Zdunkiewicz-Jedynak 2006: 260). Wielosegmentowa strona nie jest bowiem tekstem linearnym, przeznaczonym do jednokierunkowej lektury. Stanowi ona konstrukcję zapraszającą do samodzielnej wędrówki, która polega na przechodzeniu od elementu do elementu drogą wyboru czytelniczego - na poziomie technicznym sprowadza się on do kolejnych kliknięć w aktywne łącza pozwalające na tworzenie ogromnej liczby kombinacji segmentów. Twórca strony decyduje nie tylko o tym, jakie treści widoczne są w poszczególnych partiach strony; proponuje on również podział na bloki tematyczne i odpowiadające im podstrony osiągalne dzięki wewnętrznym łączom. Hierarchizacja ta w pewien sposób ukierunkowuje kolejność przejść, nie zobowiązuje jednak internauty do poddania się porządkowi czytania oraz - co równie ważne oglądania i/lub słuchania dostępnych materiałów.

Niemożliwa do odtworzenia procedura indywidualnego poruszania się po zasobach poszczególnych stron zadecydowała o ograniczeniu opisu do spostrzeżeń koncentrujących się wokół zawartości tzw. strony głównej - pierwszej, która ukazuje się na ekranie po wybraniu pełnego adresu internetowego ${ }^{5}$. Decyzji tej towarzyszy przypuszczenie, że elementy pojawiające się na stronie głównej mogły zostać przez twórców uznane za najważniejsze, bez względu na to, czy są one wszystkie pokazane w całości, czy też w postaci zapowiedzi oraz samych haseł tematycznych - linków odsyłających do dokumentu docelowego.

Zaznaczona już powyżej powtarzalność niektórych tematów podejmowanych na omawianych stronach internetowych prowokuje natomiast do postawienia pytania badawczego: czy istnieją pewne prawidłowości, modele przekazu, schematy wykorzystywane $\mathrm{w}$ zakonnych autoprezentacjach? Jeśli tak, to na jakich poziomach się one ujawniają i czy mogą mieć wpływ na odbiór?

Odpowiedź na powyższe pytania obejmie następujące aspekty, zauważalne w zakonnych autoprezentacjach:

1. podstawy identyfikacji wspólnoty,

2. obszary autocharakterystyki,

3. zaproszenie do kontaktu,

4. multimedialność.

damia tylko o organizowanych w domach wspólnoty rekolekcjach ignacjańskich. Dane na temat Zgromadzenia Sióstr Matki Bożej Miłosierdzia, zamieszczone na stronie (http://www.faustyna.pl/), podane są jako informacja drugoplanowa, podrzędna, w związku z kultem św. Faustyny [dostęp: 28.07.2014].

${ }^{5}$ Pomijam tu pozbawioną większej wartości informacyjnej ewentualną stronę wprowadzającą - tzw. wejście - zawierającą najczęściej nazwę wspólnoty i pewne wyobrażenie graficzne o wartościach symbolicznych lub tylko estetycznych, ewentualnie pozwalającą na wybór języka (np. strona klawerianek, http://www.klawerianki.pl [dostęp: 28.07.2014]). 


\section{Identyfikacja}

Wśród elementów służących identyfikacji zgromadzenia pojawia się zawsze, wyeksponowana na samej górze strony, nazwa wspólnoty. Do wyboru pozostaje pełna nazwa oficjalna (po polsku), np. Zgromadzenie Sióstr Antonianek od Chrystusa Króla, Zgromadzenie Sióstr Matki Bożej Loretańskiej ${ }^{6}$, skrócona nazwa potoczna paulistki ${ }^{7}$ oraz - stosunkowo rzadko - pełna nazwa łacińska. Nazwy oficjalne mogą być uzupełnione o skrótowiec. $Z$ wersją minimalną, obejmującą tylko jeden element, spotykamy się na stronie o nagłówku: Zgromadzenie Sióstr Rodziny Betańskiej ${ }^{8}$. Komplet danych znajduje się np. na stronie albertynek: „Zgromadzenie Sióstr Albertynek Posługujących Ubogim, ZSAPU, albertynki, Congregatio Sororum Albertinarum Pauperibus Inservientium, CSAPI". Dodatkowo wprowadza się - fakultatywnie - tekst dewizy (np. „Kochajmy Maryję i służmy Jej wiernie"10), godło (element graficzny; dewiza może być w nie wpisana, jak np. w wypadku salwatorianek czy albertynek ${ }^{11}$ ), niekiedy także wizerunek patrona lub założyciela.

Warto zauważyć, że funkcję identyfikującą może pełnić już sam adres internetowy strony. Pod tym względem najtrafniejszym rozwiązaniem wydaje się adres zawierający syntetyczną nazwę potoczną, jak np. www.paulistki.pl (podobnie np. antonianki, albertynki, kanoniczki, klawerianki, loretanki itp.), ewentualnie pełną nazwę oficjalną (o ile jest w miarę krótka, np. www.Małe-Siostry-Jezusa.org.pl). Znacznie mniej funkcjonalne, ze względu na niską wartość informacyjną, są niejednoznaczne adresy typu: http://www.siostrymisyjne.opoka.net.pl (strona sióstr służebnic Ducha Świętego), http://www.siostryfranciszkanki.pl (strona sióstr rodziny Maryi, jednego z wielu zgromadzeń o duchowości franciszkańskiej), http:// www.siostry.pl (strona sióstr salwatorianek).

\section{Obszary autocharakterystyki}

Drugim z powtarzalnych zestawów danych jest szereg informacji pozwalających opisać powstanie, typ pobożności i zadania zgromadzeń, a także ich działalność, etapy formacji oraz lokalizację domów. Wiadomości te zwykle nie są w całości dostępne na stronie głównej, można jednak do nich łatwo dotrzeć dzięki umieszczonemu tam menu (w postaci poziomej lub pionowej listy łączy, zakładek

\footnotetext{
${ }^{6}$ www.antonianki.pl; http://www.loretanki.pl [dostęp: 28.07.2014].

${ }^{7} \mathrm{Na}$ stronie http://www.paulistki.pl/wyeksponowano nazwę potoczną, poniżej umieszczono jednak oficjalną, wielowyrazową; podobne rozwiązanie: http://eucharystki.religia.net [dostęp: 28.07.2014].

${ }^{8} \mathrm{http}: / /$ www.betanki.pl [dostęp: 28.07.2014].

${ }^{9}$ http://www.albertynki.pl [dostęp: 28.07.2014].

${ }^{10}$ http://www.sluzki.pl [dostęp: 28.07.2014].

${ }^{11}$ http://www.siostry.pl; http://www.albertynki.pl [dostęp: 28.07.2014].
} 
zlokalizowanych w górnych partiach strony). Segment ten obejmuje zatem prawie zawsze takie dane, jak:

- historia wspólnoty (powstanie, założyciele, rozwój, święci wywodzący się ze zgromadzenia, np. błogosławione nazaretanki z Nowogródka ${ }^{12}$ ),

- duchowość (tu ewentualnie: reguła i patronowie),

- charyzmat,

- działalność (określana jako apostolstwo, apostolat, nasze dzieła, stużba); niekiedy rezygnuje się z wprowadzania nadrzędnego pojęcia na rzecz szczegółowego określenia działań, np. towarzyszenie $w$ żałobie ${ }^{13}$, wprowadzenia do medytacji $^{14}$, misja dworcowa ${ }^{15}$,

- formacja (etapy wkraczania w pełnię życia zakonnego; często jest to temat sąsiadujący z ,powołaniem" - informacjami dla kandydatek),

- dane adresowe (adresy, nasze domy, kontakt, placówki, w Polsce, ...na świecie, np. nazaretanki na świecie).

Powyższe informacje umieszczane są na poszczególnych stronach głównych w trzech różnych układach:

1. w postaci tekstu o charakterze lapidarnej, lecz przejrzystej pod względem graficznym noty encyklopedycznej, widocznej w całości (bloki typu: „Zgromadzenie”; „O nas”; np. na stronie albertynek ${ }^{16}$ );

2. jako rozmieszczony na całym ekranie zbiór aktywnych haseł - tematów, ułatwiających dalszą nawigację (strona nie zawiera żadnych rozbudowanych tekstów, lecz tylko nazwę zgromadzenia, symbol graficzny i linki, np. na stronach nazaretanek i marianek ${ }^{17}$ );

3. w formie łączącej opis niektórych zagadnień z listą hiperłączy (ss. wspólnej pracy, terezjanki ${ }^{18}$ ).

Wymienione zagadnienia składają się na zasadniczy korpus wiadomości ułatwiających orientację $\mathrm{w}$ charakterze zgromadzenia. Nie wszystkie realizacje są jednak przejrzyste, szczegółowa struktura strony bywa nieprzewidywalna (np. treści dotyczące apostolstwa bywały lokalizowane w działach: „O nas”, „Dzieła”, „Formacja” itp.). Informacje podaje się bezpośrednio, bez zabiegów wymagających dalszej interpretacji.

Pośrednią, bardziej skomplikowaną formą autocharakterystyki jest umieszczenie w centrum strony głównej bloku o charakterze kroniki, kalendarium lub serii artykułów, dotyczących wydarzeń z życia zgromadzenia. Wprowadzenie do takiego szeregu wiadomości z diecezji, Kościoła w Polsce i na całym świecie, fragmen-

\footnotetext{
12 http://www.nazaretanki.pl [dostęp: 28.07.2014].

13 http://www.wspomozycielki.pl [dostęp: 28.07.2014].

$14 \mathrm{http}: / /$ www.siostry-sc.pl [dostęp: 28.07.2014].

15 http://www.marianki.pl [dostęp: 28.07.2014].

16 http://www.albertynki.pl [dostęp: 28.07.2014].

17 http://www.nazaretanki.pl; http://www.marianki.pl [dostęp: 28.07.2014].

$18 \mathrm{http}: / /$ web.diecezja.wloclawek.pl/zsnm; http://www.terezjanki.pl [dostęp: 28.07.2014].
} 
tów wypowiedzi hierarchów, tekstów rozważań modlitewnych, publicystyki itp. ma zapewne na celu ulokowanie zgromadzenia na szerszym tle i wykazanie związku (fizycznego lub duchowego) z aktualnymi wydarzeniami ${ }^{19}$. Bez odpowiedniego ustrukturyzowania, otagowania lub podobnych zabiegów może jednak utrudniać odnalezienie danych bezpośrednio dotyczących wspólnoty zakonnej. Stosunkowo jasny podział kronikarskiego bloku wypracowano na stronie klawerianek, wyodrębniając działy: „Wiadomości ze świata”, „Aktualności z naszych wspólnot”20.

\section{Zaproszenie do kontaktu}

Umieszczenie autoprezentacji zgromadzeń w przestrzeni Internetu otwiera możliwości znacznie większe niż informowanie za pośrednictwem książek, broszur czy ulotek. Pozwala na szybszą, niekiedy jednoczesną komunikację, tak indywidualną, jak i widoczną dla szerszej publiczności. Rodzi się zatem pytanie, czy i w jakim stopniu odbiorca strony internetowej ma możliwość rozmowy w czasie rzeczywistym, współtworzenia treści, szybkiego przekazu informacji. Twórcy stron proponują narzędzia dosyć proste. Należą do nich: podanie adresu poczty elektronicznej, zamieszczenie formularza do korespondencji (otwierające się okno pozwala na wpisanie treści - formę tę często wykorzystuje się w ramach tzw. skrzynek intencji modlitewnych), możliwość wpisu do księgi gości, a także - w komunikacji wewnątrzzakonnej - wejście do ukrytych pól wymagających zalogowania. Ciekawsze możliwości pozostają poza ramami strony: stosowne linki odsyłają internautów do profili w mediach społecznościowych, np. do Facebooka, do rozmów za pośrednictwem komunikatora GG (niepokalanki, http://www.niepokalanki.pl/). Perspektywy interaktywności wiążą się zatem $\mathrm{z}$ wyjściem poza stronę zgromadzenia $\mathrm{i}$ o takie działania apelują gospodynie strony, np. siostry wspólnej pracy:

- Pojawiły się nowe galerie zdjęć na naszym profilu na facebooku

- https://www.facebook.com/SiostryWspolnejPracy

- Zapraszamy Was do czynnego uczestnictwa w profilu Sióstr Wspólnej Pracy na Facebooku. Czekamy na Wasze relacje z rekolekcji, wyjazdów i wyjazdów ewangelizacyjnych. Czekamy na Wasze sugestie, propozycje i wspólne przeżycia duchowe. Zacznijmy prowadzić dialog korzystając $\mathrm{z}<$ fejsbukowej> możliwości.

- Zachęcajcie znajomych, przyjaciół i tych, z którymi pragniecie podzielić się świadectwem.

- Zapraszamy również pozostałe siostry Wspólnej Pracy do interakcji na naszym profilu na Facebooku ${ }^{21}$ (http://www.siostrywspolnejpracy.pl/aktualnosci/206-siostry-na -facebooku [dostęp: 28.07.2014]).

19 Zob. np. www.wspomozycielki.pl [dostęp: 28.07.2014].

20 www.klawerianki.pl [dostęp: 28.07.2014].

${ }^{21} \mathrm{http}: / /$ www.siostrywspolnejpracy.pl/aktualnosci/206-siostry-na-facebooku [dostęp: 28.07.2014]. Niekonsekwencje w pisowni oraz wytłuszczenie zgodne $\mathrm{z}$ oryginalnym zapisem. 
Propozycje takie są wszakże zjawiskiem rzadkim. Innym sygnałem współpracy z osobami spoza zgromadzenia pozostają publikowane na stronach zakonnych wypowiedzi uczestników rekolekcji lub uroczystości.

\section{Multimedialność}

Strony internetowe żeńskich zgromadzeń zakonnych budowane są nie tylko z elementów tekstowych. Dużą rolę odgrywa grafika, zwłaszcza fotografie o charakterze zachęty (sympatyczne, często nieformalne zdjęcia pozowane, np. na tle pejzażu, z grupą roześmianej młodzieży) lub dokumentu (także serie zdjęć w odrębnych galeriach). Wiele jest również plakatów zachęcających do udziału w wydarzeniach oraz obrazów będących symbolem pewnych społeczności, akcji, publikacji, innych stron internetowych itp. Ciekawostkę stanowi strona główna sióstr paulistek: cała składa się z elementów graficznych, zawierających ukryte linki do podstron ${ }^{22}$.

W analizowanym materiale zaskakuje statyczność rozwiązań: elementem ruchomym bywa cykl fotografii zmieniających się co kilka sekund, czyli tzw. ruchomy baner (służki ${ }^{23}$ ), sporadycznie: zamieszczona na stronie głównej prezentacja typu Power Point (adoratorki $\left.{ }^{24}\right)$ lub przesuwający się napis (klawerianki ${ }^{25}$ ). Trudno odszukać filmy (dział „Filmy” na stronie głównej sióstr klawerianek, „Nasze filmiki” - u betanek ${ }^{26}$ ) lub nagrania dźwiękowe (link „Do posłuchania” - michalitki ${ }^{27}$ ). Powodem mogą być niewystarczające umiejętności administratorów strony, a także ograniczona pojemność samych stron, zwłaszcza wtedy, gdy są one fragmentem większej domeny (Opoka, strona diecezji itp.), niekoniecznie darmowej.

\section{Relacja nadawczo-odbiorcza jako źródło schematu?}

Omówione powyżej sposoby ujmowania i porządkowania treści zachęcają do pytania o ich nadawcę i odbiorcę. Nadawca jednostkowy - osoba (osoby) reprezentująca zgromadzenie, autor tekstów i konstruktor strony - zwykle pozostaje anonimowy. Ewentualne podpisy dotyczą wybranych tekstów (historycznych, przejętych z zewnątrz itp.), sygnalizują całościowe prawa własności (ewentualnie

22 http://www.paulistki.pl [dostęp: 28.07.2014].

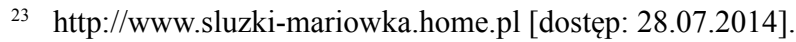

${ }^{24} \mathrm{http}: / /$ www.adoratorki.pl/ascaktual.php.pl [dostęp: 28.07.2014].

${ }_{25} \mathrm{http}: / /$ www.missionarieclaveriane.org/pol/1 pagina.htm [dostęp: 28.07.2014].

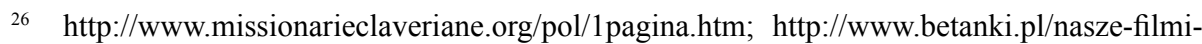
ki-3432 [dostęp: 28.07.2014].

27 http://www.michalitki.pl/articles.php?cat_id=6 [dostęp: 28.07.2014]. 
są dyskretną reklamą firmy informatycznej). Od podpisu ważniejsze wydają się środki językowe konstytuujące perspektywę nadawczą i kształt narracji: pierwszoosobowej ( $m y$, siostry) lub trzecioosobowej (one, siostry). Wybór między tymi formami nie przesądza o autorstwie tekstów zamieszczonych na stronie.

Wypowiedzi preferujące formę my ujawniającą się w zaimkach osobowych i dzierżawczych oraz w formach czasownikowych niosą komunikat o zamiarze przedstawienia wspólnoty z punktu widzenia jej samej, podkreślają wartość wewnętrznych więzi i spójność zgromadzenia, sugerują uwzględnienie rzeczywistych doświadczeń grupowych. Ujęcie odwołujące się do kategorii my, o dużej wartości perswazyjnej, podkreśla tożsamość społeczną (Łysakowski 2005: 35), uzasadnia określenie celu strony mianem bezpośredniej autoprezentacji. Na stronach głównych pojawiają się tak pojedyncze zdania tego typu: „Słowo o nas: My, zmartwychwstanki, w specjalny sposób czcimy Chrystusa w tajemnicy Jego zmartwychwstania”28; ,Jest nas 13.020 - pracujemy w 89 państwach” ${ }^{29}$, jak i obszerne, konsekwentnie redagowane teksty:

Kim jesteśmy - Zostałyśmy powołane, by być kobietami, które mówią o obecności Boga w naszym świecie i kochają do końca, aż do oddania życia. [...] Jesteśmy Zgromadzeniem międzynarodowym, które powstało ponad 200 lat temu dzięki odpowiedzi św. Magdaleny Zofii Barat na wezwanie Ducha Świętego. Tak jak ona zaproszone przez Chrystusa, radosne, bo znalazłyśmy skarb, pragniemy być Sercem Boga w świecie. [...] W naszych wspólnotach dostrzegamy coraz wyraźniej wezwanie, aby żyć naszą dewizą (http://www.siostry-sc.pl [dostęp: 28.07.2014]).

Konsekwentne posługiwanie się formami trzecioosobowymi sygnalizuje natomiast pewien dystans, czyni tekst bardziej bezosobowym, być może z założenia bardziej oficjalnym, neutralnym, niejako ukrywa autoprezentację: postać one (bez użycia zaimka) znajdujemy np. we fragmencie: „Siostry zapraszają - Siostry Urszulanki Serca Jezusa Konającego w czasie wakacji letnich 2014 roku zapraszają, jak co roku, na różne formy rekolekcji, połączonych z wypoczynkiem wakacyjnym" ${ }^{30}$. Dystans może być sygnałem dążenia do obiektywizmu, próby stworzenia wypowiedzi niezaangażowanej, sprawozdawczej, wręcz encyklopedycznej.

Przytoczone powyżej przykłady, podobnie jak wiele innych, dowodzą dominacji form liczby mnogiej. Nie zaprzecza temu sporadyczne zamieszczanie na stronie głównej wypowiedzi autoprezentacyjnych uwzględniających postać liczby pojedynczej. Funkcjonują one jako pars pro toto, przykład jednostkowy z domyślnym kwantyfikatorem wielkim. Zapis typu albertynka oznacza każdą siostrę z tego zgromadzenia, wszystkie siostry; poniższy fragment pokazuje pewien chaos w doborze form:

28 http://www.zmartwychwstanki.org.pl [dostęp: 28.07.2014].

29 http://www.cmw.osw.pl/Onas/tabid/109/Default.aspx [dostęp: 28.07.2014].

30 http://www.urszulanki.pl [dostęp: 28.07.2014]. 
Siostry albertynki odczytują swój charyzmat, wpatrując się w namalowaną przez Ojca Założyciela ikonę Ecce Homo. [...]

Albertynka ma służyć najbardziej potrzebującym bliźnim i to tym ofiarniej, im bardziej wizerunek synostwa Bożego wydaje się być zatarty czy zagubiony [...]

Albertynka winna zatem cechować się dobrocią na wzór chleba. [...]

Siostry chcą także upodobnić się do Chrystusa, który dla nas stał się ubogim. (http:// www.albertynki.pl, tekst: Duchowość [dostęp: 28.07.2014]).

Informacje na temat zakładanego odbiorcy są nader ograniczone i nie wykazują jawnego związku z omówionymi powyżej modelami narracji pierwszo- lub trzecioosobowej. Trzeba zatem założyć, że wirtualnym odbiorcą może być każdy: osoba poszukująca danych encyklopedycznych, ciekawostek dotyczących życia konsekrowanego, dziennikarz, badacz, przypadkowy internauta ${ }^{31}$. Owa niemożność precyzyjnego określenia odbiorcy może mieć wpływ na pewną przewidywalność przekazu pod względem tematycznym i formalnym, na schematyzację ujęcia. Bywa ona widoczna tak wyraźnie, że budowa strony - mimo kształtu hipertekstowego - dałaby się porównać do spisu treści tradycyjnej publikacji drukowanej $^{32}$ lub do ustalonej struktury formularza. Różnice między stronami poszczególnych zgromadzeń mogą dotyczyć miejsca umieszczenia wybranych pojęć, a w efekcie: lokalizacji podobnych bloków tematycznych. Dominuje utylitarny, sformalizowany przekaz o funkcji informacyjnej; na dalszy plan przesuwane są ewentualne elementy fatyczne oraz ocieplające wizerunek. Zaletą pewnej przewidywalności segmentów treściowych jest szansa na dotarcie do podstawowego korpusu danych oraz możliwość dokonywania ich porównawczych zestawień. Organizacja hipertekstowa pozwala czytelnikowi na wybór porządku przeglądania zbliżonych treści. Zindywidualizowanie konstrukcji stron przejawia się najwyraźniej w formach pozatekstowych, takich jak konsekwentnie dobierana symboliczna kolorystyka podstron (czerwien - adoratorki Krwi Chrystusa, dominacja błękitu - marianki), ciekawe rozwiązania graficzne przeciwstawiające się wizualnemu szablonowi lub przypadkowości, efekty akustyczne (podkład muzyczny towarzyszący przeglądaniu strony - adoratorki), dobrze zorganizowany dział multimediów. Zabiegi tego typu, sensownie zaplanowane, ułatwiają wyodrębnienie niektórych stron $\mathrm{z}$ ich ogromnego zbioru, zapamiętanie cech szczególnych, pewnych elementów treściowych oraz potencjalny powrót do wyróżniających się autoprezentacji.

Strony internetowe zgromadzeń zakonnych, zwłaszcza mniej znanych zakonów klauzurowych, stanowią niewątpliwie przykład zjawiska mediatyzacji, czyli „procesu pośrednictwa mediów w poznawaniu świata, wpływania przez media na

31 Istnieją, co prawda, dwie grupy wyróżniane na niektórych stronach - są to współsiostry (treści dla nich przeznaczone wymagają logowania) oraz osoby młode, zwłaszcza zainteresowane rozeznawaniem powołania, wprost nazywane kandydatkami.

32 Schematyzacja układu treści niektórych stron internetowych nasuwa skojarzenie $\mathrm{z}$ układem książki B. Łozińskiego Leksykon zakonów w Polsce (1998). 
postrzeganie przez człowieka rzeczywistości niedostępnej bezpośredniemu doświadczeniu" (Kołodziej 2006: 118). Pogodzenie przejrzystości i kompletności przekazu o tematyce religijnej, jego treści oraz atrakcyjnej formy uznać należy za wyzwanie, którego konsekwencją staje się napięcie między łatwo osiągalnym schematem i ryzykiem zbyt daleko idącego eksperymentu. Napięcie to nie pozostaje bez wpływu na wartości poznawcze komunikatu werbalnego i graficznego. Analizowany materiał zaprasza do kontynuowania badań - w planach pozostaje analiza genologiczna i stylistyczna tekstów lokowanych na stronach internetowych służących autoprezentacji zgromadzeń zakonnych.

\section{Bibliografia}

Bauer Z., 2006, Hipertekst [hasło], w: Stownik terminologii medialnej, red. W. Pisarek, Kraków, s. 75-76.

Borkowski I., 2011, Rzecznictwo prasowe a ksztaltowanie wizerunku polskich zgromadzeń zakonnych. Teoria - praktyka - case study, w: Ksztattowanie wizerunku jako narzędzie public relations, red. I. Borkowski, K. Stasiuk-Krajewska, Wrocław, s. 57-80.

Borkowski I., Stasiuk-Krajewska K. (red.), 2011, Ksztaltowanie wizerunku jako narzędzie public relations, Wrocław.

Czarnecka K., 2012, O internetowych słownikach języka wybranych wspólnot katolickich, w: Język doświadczenia religijnego, t. IV, red. G. Cyran, E. Skorupska-Raczyńska, Szczecin 2012, s. 51-63.

Czarnecka K, 2015a, O sposobach definiowania znaczeń leksyki religijnej w stownikach internetowych, „Poznańskie Spotkania Językoznawcze”, t. 29: Pogranicza językoznawstwa polonistycznego Prace dedykowane Profesorom Zygmuntowi Zagórskiemu i Karolowi Zierhofferowi dla uczczenia odnowienia doktoratów po pięćdziesięciu latach, red. M. Rybka, P. Wiatrowski, s. 17-35.

Czarnecka K., 2015b, Próby leksykografii religijnej w zasobach polskiego Internetu, „Poznańskie Spotkania Językoznawcze”, t. 30: Pogranicza językoznawstwa polonistycznego Prace dedykowane Profesorom Zygmuntowi Zagórskiemu i Karolowi Zierhofferowi dla uczczenia odnowienia doktoratów po pięćdziesięciu latach, red. M. Rybka, P. Wiatrowski, s. 33-43.

Goban-Klas T., 2011, Społeczeństwo masowe, informacyjne czy medialne, w: Wartki nurt mediów. Ku nowym formom spolecznego życia informacji. Pisma z lat 2000-2011, Kraków, s. 177-192.

Grzenia J., 2012, Komunikacja językowa w Internecie, Warszawa.

Jeżowska K., Treček D., 2010, Trening autoprezentacji, http://kreatywni.wsptwp.eu/wpcontent/uploads/2010/10/AUTOPREZENTACJA-materialy-szkoleniowe.pdf [dostęp: 28.07.2014].

Kloch J., 2013, Kościót w Polsce wobec WEB 2.0, Kielce.

Kloch J., 2016, Środowiska diecezji i zakonów w Polsce wobec WEB 2.0, w: Kościót. Komunikacja. Wizerunek, red. R. Kowalski, Wrocław, s. 125-137.

Kładoczny P., 2004, Proroctwa chrześcijańskie jako gatunek mowy na tle innych gatunków profetycznych, Zielona Góra. 
Kołodziej J., 2006, Mediatyzacja rzeczywistości społecznej [hasło], w: Słownik terminologii medialnej, red. W. Pisarek, Kraków, s. 118.

Łoziński B., 1998, Leksykon zakonów w Polsce, Warszawa.

Łysakowski T., 2005, Wplywowe osoby. Gramatyka i perswazja, Warszawa.

Nowak M., 2005, Świadectwo religijne. Gatunek - język - styl, Lublin.

Pisarek W. (red.), 2006, Stownik terminologii medialnej, Kraków.

Podracki J., Wolańska E. (red.), 2012, Język w mediach elektronicznych, Warszawa.

Pokorna-Ignatowicz K., 2002, Kościót w świecie mediów, Kraków.

Sarzyńska D., 2014, Funkcje wypowiedzi religijnych $w$ mediach. Perspektywa językoznawcza, w: Funkcje wypowiedzi religijnych, red. R. Przybylska, W. Przyczyna, Tarnów, s. 281-292.

Stasiuk-Krajewska K., 2011, Funkcje i struktura dziennikarskiego samoopisu-przypadek „Naszego Dziennika”, w: Ksztattowanie wizerunku jako narzędzie public relations, red. I. Borkowski, K. Stasiuk-Krajewska, Wrocław, s. 41-55.

Wojtak M., 2011, Współczesne modlitewniki w oczach językoznawcy. Studium genealogiczne, Tranów.

Zdunkiewicz-Jedynak D., 2006, Surfujac po Internecie w poszukiwaniu Boga... Gatunki komunikacji religijnej na polskich katolickich stronach internetowych, Tarnów.

Zdunkiewicz-Jedynak D., 2010, Dyskurs religijny w mediach, Tarnów. 
